\title{
ANALISIS KESALAHAN OMISSION PADA TEKS RECOUNT MAHASISWA SEMESTER VII PROGRAM STUDI PENDIDIKANBAHASA INGGRIS UNIVERSITAS ASAHAN
}

\author{
Lis Supiatman ${ }^{1}$, PutriLidiana Permata Sari $^{2}$, Rahma Yunita $\mathrm{Ansi}^{3}$ \\ Prodi Pendidikan Bahasa Inggris, FKIP UNA, Kisaran Sumatera Utara \\ nisafira202@yahoo.com ${ }^{1}$, permatasari474@yahoo.com², \\ yunitarahma500@ymail.com ${ }^{3}$
}

\begin{abstract}
ABSTRAK
Penelitian ini bertujuan untuk menemukan kesalahan omision mahasiswa dalam menulis teks recount. Penelitian ini dilaksanakan di Universitas Asahan. Subjek penelitian dalam penelitian ini adalah mahasiswa semester VII prodi bahasa Inggris Universitas Asahan sebanyak 30 orang. Penelitian ini dilaksanakan pada bulan Pebruari 2017 hingga Nopember 2017. Metodologi penelitian yang digunakan deskriptif kualitatif. Sumber data dalam penelitian ini berupa hasil tulisan mahasiswa dalam bentuk teks recount. Teknik pengumpulan data meliputi pengumpulan data dan menganalisis data. Berdasarkan hasil penelitian ditemukan bahwa mahasiswa masih banyak melakukan kesalahan dalam menghilangkan bentuk tatabahasa (omission) dengan jumlah kesalahan sebanyak 47 kesalahan. Kesalahan tersebut terjadi karena mahasiswa masih terpengaruh dengan bahasa ibu sehingga mereka masih menyamakan pola dan aturan bahasa tersebut dengan bahasa Inggris. Selain itu banyak mahasiswa yang masih memiliki kemampuan yang kurang dalam tatabahasa yang dapat dikarenakan pembelajaran yang belum optimal.
\end{abstract}

Kata Kunci: Analisis Kesalahan, Kesalahan Omission, Teks Recount

\section{PENDAHULUAN}

Menulis adalah salah satu keterampilan bahasa Inggris yang harus dikuasai oleh mahasiswa di Universitas, khususnya mahasiswa prodi pendidikan bahasa Inggris Universitas Asahan. Nurjamal, dkk (2013:4) menyatakan bahwa menulis merupakan keterampilan yang sangat kompleks. Oleh karena itu, mengombinasikan dan menganalisis setiap unsur kebahasaan dalam sebuah karangan merupakan suatu keharusan bagi penulis. Dari sinilah akan terlihat sejauh mana pengetahuan yang dimiliki penulis dalam menciptakan sebuah karangan yang efektif. Kosakata dan kalimat yang digunakan dalam kegiatan menulis harus jelas agar mudah dipahami oleh pembaca. Di samping itu, jalan pikiran dan perasaan penulis sangat menentukan arah penulisan sebuah karya tulis atau karangan yang berkualitas. Dengan kata lain, hasil sebuah karangan yang berkualitas umumnya ditunjang oleh keterampilan kebahasaan yang dimiliki seorang penulis.

Mahasiswa mengungkapkan perasaan dan ide ke dalam sebuah kata, kata menjadi frase, kata menjadi kalimat, kalimat menjadi paragraf, dan paragraf menjadi sebuah teks. Tentu saja mereka harus memahami tata bahasa yang baik. Memahami tata bahasa sangat penting di dalam menulis karena melalui pemahamam tata bahasa yang baik mereka dapat menyusun kalimat, paragraf, dan sebuah teks dengan tata bahasa yang tepat sehingga mereka dapat menyampaikan pesan mereka dengan jelas dan apa yang ditulis dapat dengan mudah dipahami oleh para pembaca.

Namun, berdasarkan hasil observasi yang dilakukan oleh penulis ketika mengajar teks Recount pada mata kuliah writing di semester $\mathrm{V}$, pada umumnya mahasiswa mengalami banyak kesalahan dalam menggunakan tata bahasa. Mereka tidak memahami tata bahasa dengan baik. Sebagai akibatnya, mereka membuat kesalahan tata bahasa ketika disuruh menulis sebuah teks Recount. Salah satu contoh kesalahan yang mereka buat adalah tenses, seperti Last week I visit my grandma in Jakarta. It should be Last week I visited my grandma. Selain itu sebagian mereka salah memilih kata ganti baik itu yang subjek maupun yang objek.

Oleh karena itu, analisis kesalahan baik dilakukan karena memiliki peran penting untuk mengungkapkan jenis kesalahan serta penyebabnya sehingga mereka dapat belajar dari kesalahan 
mereka dalam menulis. Dengan demikian, mereka tidak akan membuat kesalahan secara berulangulang. Lagi pula, setelah mereka tamat dari kampus, mereka akan menjadi seorang guru bahasa Inggris yang mana mereka juga akan mengajar teks Recount karena berdasarkan kurikulum materi teks Recount dipelajari. Bagi dosen, ini bisa menjadi evaluasi untuk pengajaran mereka karena cara pengajaran mereka juga dapat mempengaruhi kemampuan mahasiswa dalam menulis. Jadi, mereka juga dapat mengukur kemampuan mengajar mereka apakah sudah berhasil atau harus diperbaiki.

\section{Analisis Kesalahan}

Menurut Ellis (dikutip Tarigan, 2011:60) analisis kesalahan adalah "suatu prosedur kerja, yang biasa digunakan oleh para peneliti dan guru bahasa, yang meliputi pengumpulan sampel, pengidentifikasian kesalahan yang terdapat dalam sampel, penjelasan kesalahan tersebut, pengklasifikasian kesalahan itu berdasarkan penyebabnya, serta pengevaluasian atau penilaian taraf keseriusan kesalahan itu". Sementara itu menurut Tarigan (dikutip Setyawati, 2010:12) analisis kesalahan adalah "suatu prosedur kerja yang biasa digunakan oleh peneliti atau guru bahasa, yang meliputi kegiatan mengumpulkan sampel kesalahan, mengidentifikasi kesalahan yang terdapat dalam sampel, menjelaskan kesalahan tersebut, mengklasifikasi kesalahan itu, dan mengevaluasi taraf keseriusan kesalahan itu”.

\section{Faktor Penyebab Kesalahan Berbahasa}

Kesalahan merupakan sisi yang mempunyai cacat pada ujaran atau tulisan para pelajar. Kesalahan tersebut merupakan bagian-bagian konversasi atau komposisi yang menyimpang dari norma baku atau norma tepilih dari bahasa orang dewasa. Pangkal penyebab kesalahan bahasa ada pada orang yang menggunakan bahasa yang bersangkutan bukan pada bahasa yang digunakannya. Menurut Setyawati (2010:10) ada tiga faktor penyebab seseorang salah dalam berbahasa, antara lain sebagai berikut:

1. Terpengaruh bahasa yang lebih dahulu dikuasainya. Ini dapat berartibahwa kesalahan berbahasa disebabkan oleh interferensi bahasa ibu atau bahasa pertama (B1) terhadap bahasa kedua (B2) yang sedang dipelajari si pembelajar (mahasiswa).

2. Kekurangpahaman pemakai bahasa terhadap bahasa yang dipakainya.

3. Pengajaran bahasa yang kurang tepat atau kurang sempurna.

\section{Kesalahan Penghilangan (Omission)}

Ellis (1998) menyatakan bahwa, kesalahan penghilangan (Omission) adalah menghilangkan suatu kata atau unsur gramatikal yang dibutuhkan dalam suatu ungkapan yang berhubungan dengan tata bahasa. Kesalahan penghilangan yang ditemukan, diklasifikasikan sebagai berikut:

a. Kesalahan Penghilangan to be

To be terdiri atas 3 bagian yaituto be is digunakan untuk subjek She, He dan It. To be are digunakan untuk subjek You, We dan They sedangkan untuk to be am hanya digunakan untuk subjek I. Selain itu adapula jenis to be yang lain seperti was, be, were dan been yang digunakan sesuai bentuk waktu atau tenses yang ada. Contoh kalimat- kalimat di atas mengalami penghilangan to be. Pada contoh mengalami penghilangan to be is. Berikut merupakan contoh kalimat kesalahan penggunaan bentuk to be:

Today Friday our school ...

Contoh penggalan kalimat di atas seharusnya menjadi:

Today is Friday, our school ...

b. Kesalahan Penghilangan Genitive Possessive (apostrof ') yang Menyatakan Makna Kepunyaan. Menurut Gitamedia (2006), tanda apostrof digunakan bila nama benda atau nama orang yang menjadi pemilik berakhiran dengan huruf "s", dan jika tidak maka digunakan tanda apostrof $+\mathrm{s}$ $($, s). Kalimat di bawah ini mengalami penghilangan apostrof „s pada kata Stevi dan parents yang menyatakan makna kepunyaan. Kesalahan penghilangan Genitive Possessive (apostrof) yang menyatakan makna kepunyaan dapat dilihat pada contoh kalimat di bawah ini:

I fall into Stevi love

Contoh penggalan kalimat seharusnya menjadi:

I fall into Stevi"s love 
c. Kesalahan Penghilangan Preposisi

Menurut Baehaqi (2009), preposisi adalah kata yang digunakan di depan kata benda atau frase kata benda untuk menerangkan letak atau posisi benda tersebut. Pada contoh kalimat di bawah ini mengalami penghilangan preposisi of dan juga terjadi kesalahan penempatan untuk kata island dan Siau. Kesalahan penghilangan preposisi dapat dilihat pada contoh berikut:

In the Siau island

Contoh penggalan kalimat diatas seharusnya menjadi:

In the island of Siau

d. Kesalahan Penghilangan Adjective Pronoun My

Kalimat di bawah ini mengalami penghilangan adjective pronoun my yang menyatakan makna kepemilikan dan juga terdapat kesalahan penempatan untuk kata- kata village, favorite dan parents. Kemudian pada kalimat ini, terjadi penghilangan apostrof s untuk kata parents. Contoh penggalan kalimat tersebut seharusnya menjadi:

In village favorite parents

Penggalan kalimat diatas seharusnya menjadi:

In my parents"s favorite village

e. Kesalahan Penghilangan Kata Penghubung When

Kalimat pada contoh di bawah ini salah, karena menggunakan tata bahasa yang tidak beraturan juga mengalami penghilangan kata when dalam kalimat Kesalahan penghilangan kata benda when dapat dilihat pada contoh kalimat berikut:

I first followed the activities, I was little

Kalimat tersebut seharusnya menjadi:

I first followed the activities, when I was little ..

f. Kesalahan Penghilangan Auxiliary Verb "do"

Kata kerja bantu memiliki fungsi gramatikal yang sangat penting yang biasa disebut dengan auxiliary verb do (do, did, does ), biasa digunakan untuk membentuk kalimat pertanyaan dan negatif kerja bantu atau auxiliary verb. Pada contoh kalimat mengalami kesalahan penghilangan kata kerja bantu dountuk subjek I. Kesalahan penghilangan kata kerja bantu dapat ditemukan pada contoh kalimat di bawah ini:

... I not want to follow

Kalimat tersebut seharusnya menjadi:

... Ido not want to follow ..

g. Kesalahan Penghilangan Akhiran untuk Kata Benda Jamak

Dalam bahasa Inggris kata benda jamak, harus ditambahkan akhiran $-\mathrm{s}$ atau -es pada bentuk tunggalnya. Pada contoh kalimat di bawah ini mengalami penghilangan akhiran untuk kata benda jamak. Pada contoh kalimat di bawah ini kata benda thing harusnya menjadi jamak karena terdapat kata many. Kesalahan-kesalahan penghilangan akhiran untuk kata benda jamak dapat dilihat pada contoh di bawah ini:

Many thing that we felt ...

Contoh-contoh tersebut seharusnya menjadi:

Many things that we felt ...

h. Kesalahan Penghilangan Artikel "the "

Artikel "the", adalah merupakan artikel definite yang dipakai untuk menyebut kata benda secara individual. Pada contoh kalimat di bawah ini, mengalami kesalahanpenghilangan artikel "the". Kesalahan penghilangan artikel "the " terdapat pada contoh

di bawah ini :

Love at first sight ...

Contoh penggalan kalimat tersebut seharusnya menjadi:

Love at the first sight ... 


\section{Langkah-Langkah Analisis Kesalahan}

Menurut Tarigan (2011:60) mengemukakan bahwa analisis kesalahan mempunyai langkah-langkah yang meliputi:

1. Pengumpulan sampel artinya mengumpulkan data berupa kesalahan berbahasa yang dilakukan oleh mahasiswa, misalnya hasil ulangan, karangan atau percakapan

2. Pengidentifikasian kesalahan artinya mengenali dan memilah-milah kesalahan berdasarkan katagori kebahasaan, misalnya kesalahan-kesalahan pelafalan.

3. Penjelasan kesalahan artinya mengambarkan letak kesalahan, penyebab kesalahan dan memberikan contoh yang benar.

4. Pengklasifikasian kesalahan artinya mengenali dan memilah-milah kesalahan berdasarkan katagori kebahasaan

5. Pengevaluasian kesalahan artinya memperbaiki dan bila dapat menghilangkan kesalahan melalui penyusunan bahan yang tepat, buku pegangan yang baik, dan teknik pengajaran yang serasi.

\section{Teks Recount}

Menurut Djuharie (2008), Teks Recount adalah sebuah susunan kejadian yang terjadi di masa lampau. Tujuan dari jenis teks ini adalah untuk memberitahukan kejadian dimasa lampau. Teks ini dimulai dengan memberitahukan pembaca siapa yang terlibat, apa yang terjadi, dimana terjadi, dan kapan terjadi. Urutan peristiwa kemudian digambarkan di dalam beberapa urutan, contohnya urutan waktu. Susunan dari teks ini terdiri dari 3 bagian;

1. Orientasi adalah informasi tentang siapa pelaku yang terlibat dalam kejadian, serta tempat dan waktu kejadian itu terjadi.

2. Kejadian adalah urutan kejadian yang terjadi secara kronologis.

3. Kesimpulan mengungkapkan pendapat pribadi yang berkenaan dengan kejadian yang digambarkan.

Teks Recount biasanya terdiri dari ciri-ciri tata bahasa berikut:

1) Kata benda nama diri

2) Kata-kata deskriptif yang digunanakan untuk menjelaskan tentang siapa, apa, kapan, dimana, dan bagaimana.

3) Penggunaan tenses past tense

4) Kata-kata yang menunjukan susunan kejadian seperti first, next, then.

(6) Penggunaan personal pronoun yang mana pengarang bukan partisipan.

\section{TUJUAN PENELITIAN}

Penelitian ini bertujuan untuk menganalisis jenis kesalahan omission dan juga mendeskripsikankesalahan omission yang dibuat oleh mahasiswa semester VII prodi pendidikan bahasa Inggris Universitas Asahan dalam menulis teks Recount.

\section{OBJEKTIF PENELITIAN}

Penelitian ini dilakukan untuk mencapai objektif sebagai berikut:

1. Menganalisis jenis kesalahan omission yang dibuat oleh mahasiswa semester VII prodi pendidikan bahasa Inggris Universitas Asahan dalam menulis teks Recount.

2. Mendeskripsikan kesalahan omissionyang dibuat oleh mahasiswa semester VII prodi pendidikan bahasa Inggris Universitas Asahan dalam menulis teks Recount.

\section{METODE PENELITIAN}

Metode penelitian ini menggunakan deskriptif kualitatif. Metode ini bertujuan untuk menganalisis beberapa masalah atau kasus yang terjadi saat ini. Pertama, penelitian ini fokus pada masalah. Kemudian, mengumpulkan data dari mahasiswa di semester VII program studi pendidikan Bahasa InggrisUniversitas Asahan sebagai ujian esai dan menganalisis mereka.

Dalam penelitian kualitatif, instrumen adalah peneliti itu sendiri.Instrumen penelitian ini adalah tes tertulis yang akan dilakukan di kelas. Tes tertulis akan digunakan untuk mengumpulkan data 
untuk menganalisis kesalahan mahasiswa dalam menulis teks Recount, menghitung total kesalahan, dan membuat persentase kesalahan.

Teknik pengumpulan data dalam penelitian ini adalah dokumentasi. Sugiyono (2012:240), menyatakan dokumentasi adalah catatan peristiwa yang telah berlalu. Dokumentasi dalam penelitian ini adalah tes tertulis yang akan diberikan kepada mahasiswa. Para mahasiswa harus menulis teks Recount tentang pengalaman mahasiswa dalam mempelajari bahasa Inggris di sekolah. Ada beberapa langkah dalam mengumpulkan data, yaitu:

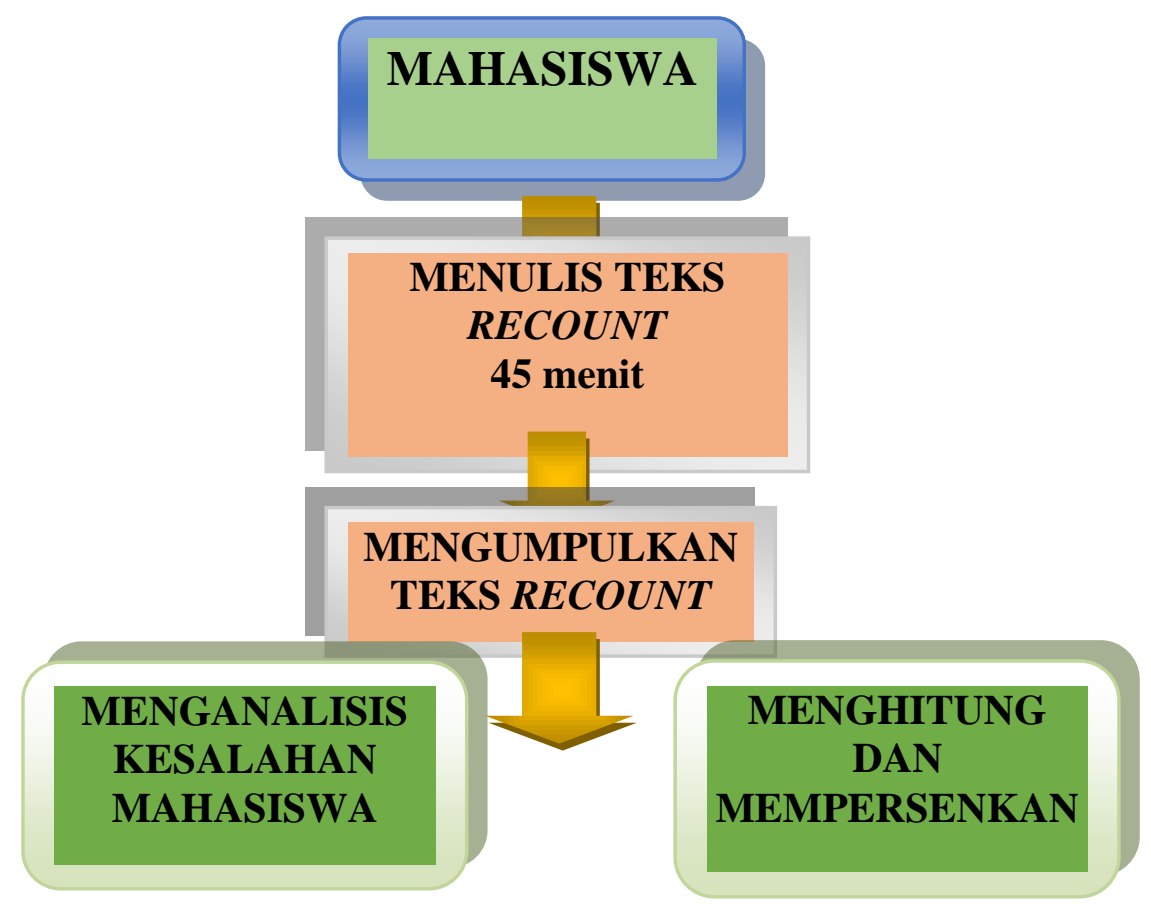

Gambar 1: Skema Pengumpulan Data

\section{HASIL DAN PEMBAHASAN}

Berdasarkan hasil penelitian diperoleh data sebagai berikut.

\begin{tabular}{|c|c|c|}
\hline \multirow{2}{*}{ No } & \multirow{2}{*}{$\begin{array}{c}\text { Inisial } \\
\text { Mahasiswa }\end{array}$} & Kesalahan \\
\cline { 3 - 3 } & Omission \\
\hline 1 & SS & 1 \\
\hline 2 & DP & 2 \\
\hline 3 & DEA & - \\
\hline 4 & SI & - \\
\hline 5 & NA & - \\
\hline 6 & HPS & - \\
\hline 7 & FAS & 2 \\
\hline 8 & SH & 1 \\
\hline 9 & WWA & 1 \\
\hline 10 & FS & 1 \\
\hline 11 & NMS & 1 \\
\hline 12 & HP & 2 \\
\hline 13 & TR & - \\
\hline 14 & RAS & 2 \\
\hline 15 & HUL & 3 \\
\hline 16 & SA & - \\
\hline
\end{tabular}




\begin{tabular}{|c|c|c|}
\hline 17 & RKBT & 3 \\
\hline 18 & IS & 15 \\
\hline 19 & KBS & 1 \\
\hline 20 & RN & - \\
\hline 21 & NF & 1 \\
\hline 22 & NH & 1 \\
\hline 23 & MBB & - \\
\hline 24 & DP & 5 \\
\hline 25 & DT & - \\
\hline 26 & DI & 2 \\
\hline 27 & RA & - \\
\hline 28 & DDP & - \\
\hline 29 & A & 2 \\
\hline 30 & ENS & 1 \\
\hline & Total & $\mathbf{4 7}$ \\
\hline
\end{tabular}

Tabel 1.1 Rekapitulasi Kesalahan Omission Mahasiswa dalam Menulis Teks Recount

Berdasarkan tabel rekapitulasi di atas, peneliti menganalisa kesalahan omission mahasiswa dalam menulis teks recount sebagai berikut:

a. Kesalahan Penghilangan to be

Seperti yang dibuat oleh mahasiswa nomor 2 because the teacher killer. Dari kalimat tersebut ada to be yang dihilangkan yaitu was. Kalimat tersebut seharusnya menjadi the teacher was killer. Kemudian kalimat yang dibuat mahasiswa nomor 8 the best teacher is a teacher who able to speak English.To be is seharusnya ada sebelum kata able sehingga menjadi the best teacher is a teacher who is able to speak English. Kesalahan ini terjadi karena mahasiswa masih terpengaruh dengan bahasa Indonesia. Dalam bahasa Indonesia tidak mengenal adanya to be. Mereka menterjemahkannya ke dalam bahasa Inggris secara langsung tanpa mempertimbangkan pemakaian to be sebagain auxiliary verb.

\section{b. Kesalahan Penghilangan Preposition}

Ada mahasiwa yang menghilangkan preposition di dalam kalimat. Itu terjadi dikarenakan memang mahasiswa kurang paham akan pemakaian preposition dalam kalimat sehingga ketika menterjemahkannya ke dalam bahasa Inggris preposition tersebut tidak dimasukkan di dalamnya. Seperti kalimat yang di tulis oleh mahasiwa nomor 1 there is one thing my experience. Kalimat tersebut seharusnya menjadi there is one thing in my experience. Preposition in tersebut menyatakan posisi dimana satu hal tersebut ada.

c. Kesalahan Penghilangan Genetive Possessive (apostrof ')

Kesalahan penghilangan Genetive Possessive juga terjadi ketika mereka menyatakan kepemilikan. Dalam bahasa Indonesia tidak ada mengenal pemakaian aposrof ' untuk menyatakan kepunyaan sehingga ketika mereka mengubahnya ke dalam bahasa Inggris apostrof ' tidak dicantumkan. Kesalahan tersebut dapat dilihat di kalimat yang dibuat oleh mahasiswa nomor 7 the teacher science conveyed by the teacher will not be observeb. Seharusnya teacher's science karena kata science itu miliknya teacher.

d. Kesalahan Penghilangan Artikel the

Mahasiswa kurang paham menggunakan artikel thedalam kalimat. Ketika menterjemahkan ke dalam bahasa Inggris mereka pun lupa meletakkan theuntuk menyatakan sesuatu yang sudah tertentu. Seperti kalimat yang dibuat oleh mahasiswa nomor 14 I have not understood about narrative text but after teacher English explain. Seharusnya sebelum kata teacher harus ada artikel the yang mendahuluinya karena teacher tersebut sudah tetentu. 


\section{KESIMPULAN}

Berdasarkan data yang telah diuraikan sebelumnya, peneliti dapat menyimpulkan bahwasanya mahasiswa banyak melakukan kesalahan dalam menghilangkan bentuk tata bahasa (omission) dengan frekuensi kesalahan sebanyak 47 kesalahan. Kesalahan tersebut terjadi karena mahasiswa masih terpengaruh dengan bahasa ibu sehingga mereka masih menyamakan pola dan aturan bahasa tersebut dengan bahasa Inggris. Selain itu banyak mahasiswa yang masih memiliki kemampuan yang kurang dalam tata bahasa yang dapat dikarenakan pembelajaran yang belum optimal.

\section{RUJUKAN}

Baehaqi, I. 2009. A Handbook of English Grammar. Yogyakarta: Media Ilmu Djuharie, O.S. 2008. Genre Text. Bandung: YramaWidya

Ellis,R. 1998. Second Language Acquisition.New York: Oxford University Press

Gitamedia, T. 2006. Serious English for Serious Students. Surabaya:Gitamedia Press Nurjamaldkk, 2013. Terampil Mengarang. Bandung: Alfabeta.

Razaq, O. 2010. 21 Siasat Dosis Tinggi Melawan Toefl. Yogyakarta: Pustaka Widyatama

Setyawati. 2010. Analisis Kesalahan Berbahasa Indonesia. Surakarta: Yuma Pustaka

Sugiyono . 2012. Metode Penelitian Kuantitatif, Kualitatif, dan R\&D.Cetakan ke-17. Bandung: Alfabeta.

Tarigan, H. G. 2011. Pengajaran Analisis Kesalahan Berbahasa. Bandung: Angkasa 